\title{
Aikuiskoulutuksen "uuteen" tulemiseen koulutussuunnittelun perinteisin menetelmin
}

Kivinen Osmo, Rinne Risto, Ahola Sakari \& Kankaanpää Arto. 1988. Aikuiskoulutuksen "uuteen" tulemiseen koulutussuunnittelun perinteisin menetelmin. Aikuiskasvatus 8, 4. 4-10. - Artikkelissa tarkastellaan Väestön koulutus 2000 -mietinnön käyttämiä määrällisen koulutussuunnittelun menetelmiä ja aikuiskoulutuksen tavoitteenasetteluja. Erityisesti huomiota kiinnitetään vaihtoehtoisten työvoimaennusteiden käyttämiseen ja koulutuksen kysyntämenetelmän mahdollisuuksiin, väestön koulutusprefenssien selvittämisen tärkeyteen, aikuiskoulutuksen laajentamisen ongelmiin ja koulutuksen osuuteen rakennemuutoksen hallinnassa.

\section{Väestön koulutus 2000}

Koulutussuunnittelun neuvottelukunta on tuottanut julkisuudessakin jo 1980-luvun keskeiseksi koulutusasiakirjaksi mainitun mietinnön vuoden 2000 koulutuksen määrällisistä tavoitteista (KM 1988:28).

Koska Matti Haavio esitteli mietinnön numeerista sisältöä Aikuiskasvatuksen viime numerossa, emme puutu siihen lähemmin. Sen sijaan pyrimme pureutumaan numeroiden, ennusteiden ja koulutustavoitteiden taustalla oleviin oletuksiin ja intresseihin sekä määrällisen koulutussuunnittelun ongelmiin ja tulevaisuudennäköaloihin oletetun rakennemuutoksen kontekstissa.

Väestön koulutus 2000 -mietintö on nuoruusiän koulutuksen osalta puhdaslinjainen työvoimamenetelmän sovellutus, missä koulutuspaikat on jaettu arvioidun ammattirakennekehityksen mukaisesti (vrt. Haavio 1988, 31). Suomessa väestön koulutushalukkuuden ja -preferenssit huomioon ottava koulutuksen kysyntämenetelmä ei näytä missään vaiheessa ottaneen tuulta, vaan koulutussuunnittelu on ollut pitkälti alisteinen työvoimasuunnittelulle. Tällä hetkellä koulutuksen kysyntä ja työelämän tarpeet menevät kuitenkin pahasti ristiin useilla aloilla. Työvoimamenetelmän dilemmana onkin se tosiasia, että työelämän tarpeet eivät tyydyty, jos koulutuspaikkoja lisätään sinne, missä koulutukselle ei ole kysyntää.

Myöskään koulutuksen kustannus-hyöty -analyysiá ei ole Suomessa laajasti sovellettu. Koulutuksen taloustiedettä on vierastettu lähinnä siksi, että koulutuksen tuotto on vaikeasti mitattavissa ja luottamus eri indikaattoreihin vähäistä. Niinpä tutkimustietoakin koulutuksen taloudellisista ja muista tosiasiallisista hyödyistä ja haitoista on vähän. Kaikesta huolimatta suunnittelukoneisto toimii jatkuvasti ekspansiivisen koulutuspolitiikan hengessä.

Mietintö painottuu voimakkaasti aikuiskoulutukseen yksinkertaisesti siksi, että tulevaisuudessa eivät pienenevät nuorisoikäluokat riitä tyydyttämään kasvavaksi arvioitua työvoimatarvetta. Osaltaan tilannetta pahentaa koulutus itse: lisääntyvä koulutukseen osallistuminen vähentää nuorten ikäluokkien tarjontaa työmarkkinoilla.

Mietinnössä on usein vaikeata erottaa toisistaan laskennallisia tarpeita, ei-laskennallisia tarpeita ja tavoitteita. Nuoruusiän koulutus on jaettu puhtaasti funktionaalisesti (vrt. Haavio 1988, 31) eri ammattiryhmien osalle. Jossain kohdin on lisäksi jouduttu käyttämään harkintaa: esim. alkutuotannon lohko näyttäisi pelkkien laskelmien mukaan kuihtuvan lähes olemattomiin. Koulutuspaikkoja sille on kuitenkin 
varattu jo nyt voimassa olevien suunnittelupäätösten mukaan runsaasti, jopa siinä määrin, että mm. Tiuri $(1986,154)$ on saanut aiheen kysyä, onko Suomi palaamassa kohti maatalousyhteiskuntaa. Aikuisväestön koulutuksessa puolestaan painottuvat asetetut tavoitteet, vaikka laskelmat onkin neuvottelukunnan (s. 106) mukaan kytketty työvoiman tarjontaan. Vuodeksi 2000 kaavaillut aikuiskoulutuksen 50000 aloituspaikkaa vastaavat noin kahta prosenttia työvoimasta.

Artikkelimme aluksi vertaamme neuvottelukunnan käyttämää työvoimaennustetta työvoimaministeriön ennusteeseen ja tarkastelemme ennustamiseen sekä työvoimamenetelmään liittyviä ongelmia. Tämän jälkeen tarkastelemme koulutuksen kysyntää ja väestön koulutuspreferenssejä, jotka periaatteessa sisältyvät neuvottelukunnan malliin, mutta käytännössä puuttuvat, sillä niitä koskevaa luotettavaa tutkimustietoa ei ole. Seuraavaksi tarkastelemme muutamia aikuiskoulutukseen liittyviä ongelmia ja lopuksi pyrimme eksplikoimaan niitä ehtoja, jotka määrittävät koulutuksen osuutta rakennemuutoksen hallinnassa.

\section{Vaikeuksien ennustaminen ja ennustamisen vaikeus}

Neuvottelukunta sanoo käyttämänsä lähestymistavan ottavan huomioon koulutuksen määrällisen suunnittelun keskeiset menetelmät, (1) koulutuksen kysynnän, (2) koulutuksen kustannusten ja hyötyjen väliset suhteet ja (3) koulutetun työvoiman tarpeen (s. 2). Mietinnössä painottuu kuitenkin voimakkaasti koulutetun työvoiman tarvetta korostava suunnittelu. Koulutuksen hyötyjen ja kustannusten välisiä suhteita ei pohdita lainkaan eikä subjektiivista koulutuskysyntää tunneta.

Neuvottelukunta arvioi rakennemuutoksen tuovan mukanaan työn teknistymisen (s. 3153), työvoiman kysynnän ja tarjonnan alueellisten erojen kärjistymisen (s. 86), ammatinvaihtojen moninkertaistumisen $(\mathrm{s} .28,84)$ sekä ammattitaitovaatimusten kohoamisen ja ammattitaidon nopean vanhenemisen (s. 18, 28).

Oletettu rakennemuutos vaikeuttaa elinkeino- ja ammattirakenteen kehityspiirteiden tarkkaa ennakointia. Rakennemuutoksen todennäköisiin kulkusuuntiin vaikuttavat myös monet talous-, yhteiskunta- ja koulutuspoliittiset ratkaisut. Esim. työajan jakaminen ja työllisyysasteen kehitys määrittävät keskeisesti aloittaista työvoimatarvetta. Tästä huolimatta neuvottelukunta esittää vain yhden todennäköisemmäksi sanotun ennusteen (s. 28), mutta ei kerro, miksi juuri tämä ennuste on hyvä.

Sen lisäksi, että neuvottelukunta perustaa koulutuksen tarvearvionsa tehtyyn ammattirakenne-ennusteeseen, se on joutunut huolellisesti ottamaan huomioon myös valtioneuvoston aikaisemmin tekemät päätökset ammatillisesti eriytyvän koulutuksen kehittämisestä. Alan teoksissa koulutussuunnittelu mielletään välineeksi halutun kaltaisen tulevaisuuden saavuttamiseksi tai jopa hallitsemiseksi (esim. Lehtisalo \& Raivola 1986, 182), joten on syytä pohtia minkälaisesta tulevaisuudesta on kysymys ja ennen kaikkea, onko muita yhtä todennäköisiä tulevaisuuksia tarjolla.

Tutkimuksen näkökulmasta mietintö on esitystavaltaan sikäli kiusallinen, ettei läheskään aina selviä, millaisiin oletuksiin esitetyt luvut perustuvat ja miten eri laskelmat liittyvät toisiinsa. Niinpä olemme joutuneet tyytymään melko karkeaan työvoimaennusteiden vertailuun ja koulutuspoliittisten seurausten arviointiin.

Neuvottelukunnan varapuheenjohtaja Aulis Lintusen eriävän mielipiteen mukaan neuvottelukunnan keskusteluissa ei ole pohdittu eikä jäsenille pyynnöistä huolimatta kerrottu, millaiselle taloudelliselle kehitykselle esitetty arvio perustuu. Laskelmissa on kuitenkin ilmiselvästi lähdetty täystyöllisyydestä.

Mitä tämä vaihtoehtoisten ennusteiden poisjättäminen on sitten tuonut mukanaan? Asiaa voidaan valaista vertailemalla Taloudellisen suunnittelukeskuksen (TASKU) ja työvoimaministeriön (TVM) ennusteita työllisen työvoiman toimialoittaisesta jakautumisesta vuonna 1995'. Vertailun kohteena ovat nimenomaan työvoiman kysynnän ennusteet. Neuvottelukunnan käyttämä toimialaennuste on keväällä 1987 tehty tarkiste TASKUn kaksi vuotta vanhemmista laskelmista (s. 26).

${ }^{1}$ Olemme toisaalla käsitelleet yksityiskohtaisemmin työ-
paikkakehityksen ennustamista ja koulutussuunnittelua. 
Taulukko 1. Työvoiman toimialoittainen kysyntä Taloudellisen suunnittelukeskuksen (TASKU) ja työvoimaministeriön (TVM) ennusteiden mukaan (3\%, 2,5\% ja 2\% bruttokansantuotteen vuotuinen kasvu) vuonna 1995, (1000 henkilöä)

\begin{tabular}{|l|crrr|rrr|}
\hline \multirow{2}{*}{ Toimiala } & TASKU/ & \multicolumn{3}{c|}{ TVM } & \multicolumn{3}{c|}{ TASKU - TVM } \\
& N-KUNTA & $3 \%$ & $2.5 \%$ & $2 \%$ & $3 \%$ & $2.5 \%$ & $2 \%$ \\
\hline Maa- ja metsätalous & 233 & 186 & 184 & 183 & +47 & +49 & +50 \\
Teollisuus & 571 & 555 & 533 & 512 & +16 & +38 & +59 \\
Rakennustoiminta & 160 & 178 & 176 & 169 & -18 & -16 & -9 \\
Kauppa & 375 & 384 & 375 & 370 & -9 & 0 & +5 \\
Liikenne & 189 & 169 & 167 & 163 & +20 & +22 & +26 \\
Rahoitus ja vakuutus & 176 & 192 & 185 & 181 & -16 & -9 & -5 \\
Yhteiskunnalliset ja yksityiset & 820 & 810 & 801 & 787 & +10 & +19 & +33 \\
palvelukset & 5 & 3 & 3 & 3 & $(+2)$ & $(+2)$ & $(+2)$ \\
Tuntematon & 2529 & 2477 & 2424 & 2368 & +52 & +105 & +161 \\
\hline Yhteensä & $(77)$ & 115 & 157 & 201 & & & \\
Työttömiä & $(3.0)$ & 4.4 & 6.1 & 7.8 & & & \\
Työttömyysaste & & & & & & & \\
& & & & & & &
\end{tabular}

Lähteet: Väestön koulutus 2000, taulukot 5, 7, 9, 11,13, 15 ja 17; Työmarkkinoiden tulevaisuus, taulukot 1.4 ja 3.1.

Huomautus: TASKUn ennusteen työttömyysaste ja työttömien määrä on tässä poimittu alkuperäisestä ennusteesta (Suomen kansantalouden..., 31). Näitä lukuja ei siis esitetä neuvottelukunnan mietinnössä.

Taulukosta 1 havaitaan, että TVM:n ennusteisiin verrattuna koulutussuunnittelun neuvottelukunnan hyväksymä TASKUn työllisyysennuste on huomattavasti optimistisempi. Kolmen prosentin bruttokansantuotteen vuotuiseen kasvuun perustuva TVM:n päävaihtoehto ennustaa työllisen työvoiman määrän 52000 henkilöä pienemmäksi kuin TASKU, kun taas hitaan kasvun ennuste (2 \%) tuottaa jo 161000 henkilön eron.

Tarkasteltaessa toimialoittaisia eroja havaitaan maa- ja metsätaloudessa toimivan työvoiman määrän vähenevän TASKUn mukaan hitaammin kuin TVM:n ennusteissa. Teollisuuden kohdalla tilanne on samansuuntainen. Muidenkin toimialojen työllisyyden kehitysennusteet eroavat huomattavasti. Ainoastaan kaupan kohdalla TASKUn ja TVM:n ennusteet osuvat kutakuinkin yhteen.

Jos neuvottelukunnan käyttämä versio TASKUn ennusteesta on todella syntynyt työmarkkinapoliittisen neuvottelun tapaisena lopputuloksena, kuten eriävästä mielipiteestä voidaan lukea (s. 286), merkitsee se myös sitä, että erityisesti maa- ja metsätalouden mutta myös teollisuuden, liikenteen sekä yhteiskunnallisten ja yksityisten palvelusten intressejä edustavat jäsenet ovat saaneet alansa työllisyyskehityksen näyttämään suotuisammalta kuin virkamiehistä koostuva ennusteryhmä omissa arvioissaan.

Ennustetun rakennemuutoksen työttömyysja uudelleenkoulutuspaineet näyttävät kohdis- tuvan ennen muuta maa- ja metsätalouteen mutta myös teollisuuteen. Työvoimatarpeet kohdistuvat puolestaan lähinnä yhteiskunnallisiin ja yksityisiin palveluksiin ja jossain määrin myös kauppaan sekä rahoitus- ja vakuutustoimintaan.

Rakennemuutoksen työvoimapoliittiset vaikutukset näkyvät myös verrattaessa työvoimamuutoksia supistuvilla ja kasvavilla toimialoilla. Kun rakennemuutos koskisi TASKUn ennusteen mukaan yhteensä noin 278000 työpaikkaa, niin TVM:n ennusteiden perusteella noin $335000-354000$ työpaikkaa siirtyisi alalta toiselle. Vastaavasti koulutustarve näyttäisi TVM:n ennusteissa olevan suurempi. Supistuvilta aloilta vapautuvan työvoiman uudelleenkoulutuspainetta kuitenkin helpottaa työvoiman luonnollinen poistuma.

Koulutussuunnittelun neuvottelukunta ei mitenkään reagoi työvoimaministeriön ennusteisiin, vaikka sillä on ollut ne käytettävissään (s. 103) ja vaikka työvoimaministeriöllä on ollut edustajansa neuvottelukunnassa. Toisaalta oletukset täystyöllisyydestä ja ammattirakenne-ennusteen kasvuvoittoisuus ovat olleet osaltaan luomassa tilannetta, missä on ollut paljon koulutuspaikkoja jaettavana.

Koulutussuunnittelun tulisi varautua moniin mahdollisiin tulevaisuuksiin. Erilaiset työvoimaennusteet antaisivat viitteitä siitä, miten suuria eri ammattiryhmien koulutustarve-erot voivat tulevaisuudessa olla. Koulutustarpeen 
keskiarvon ennustamista hyödyllisempää olisi sen ääripäiden, hajonnan arviointi. Sen jälkeen voitaisiin pohtia, miten koulutuksen kysyntä ja tarjonta sovitetaan tähän arvioon.

Tällä hetkellä lähes 90 \% ikäluokasta hankkii jonkinlaista perusasteen jälkeistä ammatillista koulutusta. Kaikki eivät kuitenkaan suorita tutkintoa. Vuoden 1985 tietojen mukaan (SVT VI, C:107) 73 prosentilla 25-34-vuotiaista on vähintään alemman keskiasteen koulutus ja 67 prosentilla kyseessä on ammatillisesti eriytynyt koulutus; 35-44-vuotiaista hieman yli puolet ja 45-54-vuotiaista enää runsas kolmannes on saanut ammattikoulutuksen.

Neuvottelukunnan näkemyksen mukaan huomattavaa aikuisväestön peruskoulutustarvetta esiintyy vielä pitkään (s. 102). Koulutuksen asianmukaiseksi organisoimiseksi olisi tiedettävä keitä nämä heikosti peruskoulutetut ihmiset ovat ja mitä he tekevät, mitkä ovat heidän työmarkkina-asemansa, koulutupreferenssinä ja alttiutensa liikkuvuuteen. Mietinnön mukaan väestön koulutushalukkuuden intensiteetistä ja suuntautumisesta kertovaa tutkimus- ja tilastotietoa on kuitenkin niukasti. Tämän vuoksi neuvottelukunnan suunnitelmat perustuvat osin arvauksiin.

Neuvottelukunta on asettanut numeeristen ennusteittensa lähtökoı daksi kolme periaatetta (s. 132). Ensinnäkin koulutusmahdollisuuksia tarjotaan siten, että väestön koulutustarpeet voidaan tyydyttää. Toiseksi koulutus kohdennetaan työelämän tarpeiden mukaisesti vastaamaan esitettyä työelämän muutosta. Kolmannen periaatteen mukaan koulutuksella voidaan myös vaikuttaa yhteiskunnan ja työelämän kehitykseen, jolloin koulutuksen määrällisiä tavoitteita ei välttämättä tarvitse johtaa suoraan työvoiman tarpeesta.

Neuvottelukunta ei täsmennä, mitä kolmas periaate käytännössä tarkoittaa. Mutta mitä ilmeisemmin se liittyy talouden ja työllisyyden kytkentöihin siten, että koulutusta pidetään tärkeänä tuotannontekijänä lisäämässä tuottavuutta, parantamassa kilpailukykyä ja luomassa työpaikkoja. Erityisesti korkeasti koulutettujen ajatellaan pystyvän itse luomaan itselleen työpaikkoja. Käytännössä tätä ei kuitenkaan ole kyetty ottamaan huomioon, vaan ainakin nuoruusiän koulutuksen osalta koulutustarve on laskettu melko suoraviivaisesti työelämän tarpeesta ammatissatoimivuuteen, opintojen jatkamiseen ja opintojen läpäisyyn liittyvien kertoimien avulla (vrt. KM 1988:28 liite 14).

Neuvottelukunta myöntää, että kaksi ensimmäistä periaatetta ovat ristiriidassa keskenään.
Väestön koulutushalukkuus ei täsmää työelämän tarpeisiin. Tarkemmin perustelematta neuvottelukunta väittää, että sen esittämät jatko-opintomahdollisuuksien ja aikuiskoulutuksen laajennukset lieventäisivät kyseistä ristiriitaa. Näinköhän esimerkiksi metallialan lattiatason tehtävien työvoimapula eliminoituisi aikuisille tarkoitettujen ammattikoulupaikkojen avulla?

Subjektiivisen koulutuskysynnän huomiotta jättäminen on kohtalokasta juuri siksi, että ammatillista koulutusta ollaan painottamassa aikuiskoulutuksen suuntaan (s. 8, 21, 28). Aikuisiässä taloudelliset, sosiaaliset ja psykologiset esteet ammatilliseen koulutukseen voivat olla huomattavasti suuremmat kuin nuorena. Yhteiskuntapoliittisesti olisi arveluttavaa päätyä aikuisten "pakkokouluttamiseen". Tätähän tosin jo tapahtuu työllisyyskoulutuksessa, kun työttömät joutuvat vastoin tahtoaankin osallistumaan usealle erilaiselle työllisyyskurssille säilyttääkseen sosiaaliset etunsa. Pakkokouluttaminen selvästi kärjistäisi jo nyt havaittua uutta poikkeavuusjakoa koulutushalukkaisiin ja koulutushaluttomiin. Neuvottelukunta (s. 17) toteaa itsekin, että sı!uri osa työttömistä on rakennemuutoksessa syrjäytyneitä, ikääntyneitä ja eläkkeellepääsyä odottavia, joiden kouluttaminen uusiin tehtäviin ei ole yksinkertaista.

Kun näillä eväillä väestön ja työelämän intressien ristiriita ei näytä - ratkeavan, joutuu neuvottelukunta heti lieventämään periaattellisia tavoitteitaan (s. 233): Lähtökohtana on "koulutuksen kohdentaminen eri aloille ja koulutusasteille siten, että sekä työelämän että mahdollisuuksien mukaan nuorten koulutushalukkuus otetaan tarkoituksenmukaisesti huomioon". Tämän formuloinnin ongelmallisuus käy hyvin esiin neuvottelukunnan tarkastellessa koulutustarvetta ja sen perusteita koulutuslohkoittain.

Mietinnössä käsitellään koulutuslohkoja monipuolisesti, kun mm. koulutuksen yleiset periaatteet, ammattirakenteen muutokset, eri alojen erityistarpeet sekä väestön koulutushalukkuus otetaan huomioon. Väestön koulutuspreferenssien ongelmaan tarjotaan yleiseksi patenttilääkkeeksi tekniikan kehitystä, siis samaa prosessia, joka on rakennemuutosongelmien taustalla. Neuvottelukunta uskoo, että tekniikan kehitys ja teknologisten innovaatioiden käyttöönotto lisäävät nuorten koulutushalukkuutta niillä aloilla, joilla se tällä hetkellä on vähäistä ja ylläpitää sitä aloilla, joilla koulutushalukkuutta on riittävästi. Toisaalta neuvottelukunta uskoo, että halukkuus esim. tekniikan koulutuslohkon ongelma-aloille lisääntyy tuottavuuden ja työllisyyden kohentuessa. Ilmeisen järkevää onkin ajatella, että nuoret 
eivät hakeudu aloille, joilla työnsaantimahdollisuudet näyttävät kehnoilta.

Esimerkiksi alkutuotannon lohkolla neuvottelukunta arvelee koulutustarpeen olevan suuremman kuin elinkeinon supistumisesta voisi päätellä. Jo tehtyjen tavoitepäätösten mukaan alkutuotannossa olisi 1990-luvun alussa 5825 aloituspaikkaa, kun esim. vuonna 1987 aloittaneita oli 4 500. Neuvottelukunnan kokonaistavoite on 8790 aloituspaikkaa vuonna 2000 ja siitä aikuiskoulutuksen osuus on $52 \%$. Neuvottelukunta uskoo, että "maatalouden parissa tai sen lähellä toimivat kiinnostuvat vastaisuudessakin alan koulutuksesta". Lisäksi alkutuotannon "pitkälle erikoistuneet alat saattavat houkutella jossain määrin sitä kaupunkilaisväestöä, jonka juuret ovat maalla". Tekniikan kehityksen, erityisesti biotekniikan mukaantulon uskotaan lisäävän kiinnostusta maa- ja metsätalouteen, mikä näkyy varsinkin alan tieteellisessä koulutuksessa.

Täysin toisen kuvan kiinnostuksesta antavat kuitenkin ammatillisen koulutuksen aloittaneita koskeneet luvut. Esim. maatila- ja metsätalouden yleisjaksoilla täyttöasteet ovat selvästi pudonneet vuodesta 1986 vuoteen 1987, vaikka samaan aikaan aloituspaikat vähenivät yli 200:lla. Kouluasteella aloituspaikkoja jäi täyttämättä 1262 vuonna 1987. (Tilastotiedotus KO 1987:20; 1988:4)

Neuvottelukunta painottaa alkutuotannon ammattien kohdalla sivutöiden merkitystä, mutta niillä voidaan perustella ilmeisesti vain osaa ylimitoitetulta näyttävästä koulutustarjonnasta. Vaikka mietinnössä todetaan sivuansioiden lisääntyvän, ei eksplisiittisesti aseteta tavoitteeksi kahteen ammattiin kouluttamista.

Sen lisäksi, ettei ole mitenkään selvää, toteutuuko neuvottelukunnan kaavailema ammattirakenteen muutos, myöskään siitä ei ole mitään takeita, että suunnitellut koulutuspaikat tyydyttäisivät arvioidun työvoimatarpeen. Näin myös tämä mietintö vahvistaa jo aiemminkin tiedettyä tarvetta etsiä uusia koulutussuunnittelun lähtökohtia ja välineitä.

\section{Aikuisväestön koulutuksen ongelmat}

Neuvottelukunta on omaksunut yhdeksi johtoajatuksekseen jatkuvan koulutuksen (s. 28). Vaikka valtioneuvosto asetti jo vuoden 1978 periaatepäätöksessään jatkuvan koulutuksen koko koulujärjestelmän kehittämisperiaatteeksi, ei vieläkään tiedetä mitä jatkuva koulutus oikein on. Esimerkiksi Suomen Akatemia "pisti jäihin" kampanjoimansa jatkuvan koulutuksen tutkimusohjelman hankkeet $\mathrm{mm}$. siksi, ettei tiedetty mitä jatkuvalla koulutuksella tarkoitettiin, eivätkä tehdyt projektitarjouksetkaan liitty- neet näin riittävän tarkasti jatkuvaan koulutukseen. Vaikka Suomessa jatkuva koulutus "lanseerattiin" aikuiskoulutuksen suunnitteluorganisaation toimesta, on se määrätietoisesti haluttu tulkita koko koulutusjärjestelmää koskevaksi, mikä poikennee muitten Pohjoismaitten tulkinnasta.

Käytännössä kaikentasoiset ja -ikäiset työntekijät ovat aina kehittäneet itseään. Työntekijöiden työssään hankkima ammattitaito on yksi suomalaisen hyvinvoinnin avaintekijöistä. Siihen liittyy usein myös voimakas ammattiylpeys. Nyt tämä ammattitaito aiotaan ainakin osittain institutionalisoida systemaattisen koulutusjärjestelmän piiriin. Neuvottelukunnan mukaan "aikuisväestön koulutukseen soveltuvat useassa tapauksessa koulutuksen normaalijärjestelyt. Käytettävissä tulee kuitenkin olla riittävästi aikuisväestön erityistarpeisiin soveltuvia järjestelyjä" (s. 105). Pannaanko nyt kredentialistiset ja meritokraattiset ihanteet, jotka ovat olleet lähinnä ylemmälle keskiluokalle ominaisia, läpäisemään kaikki kansankerrokset?

Mikä sitten on aikuisväestön koulutustarve? Neuvottelukunta tarkoittaa aikuisväestön koulutuksella työelämässä tai työelämän käytettävissä olevien aikuisten koulutusta (s. 104). Riippuen siitä, minkälaisia oletuksia asetetaan työttömyydelle, päädytään hyvin erilaisiin skenaarioihin.

Mekaanisesti laskien nuoruusiän koulutus tyydyttää suurimman osan työvoiman kysynnästä. Vain 8400 paikkaa jää täyttämättä. Mikäli neuvottelukunta lähtee täystyöllisyydestä, ei vajetta voida täyttää kouluttamalla aikuisia. Jos työttömyys puolestaan pysyy nykytasolla, mihin sijoittuvat loput 50000 aikuiskoulutettavasta? Ainakin koulutetun työvoiman saatavuus näyttää neuvottelukunnan suunnitelmien valossa hyvin turvatun.

Vaikka aikuiskoulutus kytkeytyy oleellisesti työttömyyden hoitoon, asia jää mietinnössä epäselväksi (ks. s. 127-128). Neuvottelukunnan kaavailema aikuiskoulutus aiheuttaa työttömyysoletuksesta riippuen työvoiman lisätarvetta, jota kuitenkaan "ei ole voitu laskennallisesti ottaa kovin suuressa määrin huomioon" (s. 82). Käytännössä tarve tyydyttyy usein siten, että osa työntekijöistä joutuu tekemään kahta työtä.

On aivan eri asia kouluttaa työttömiä kuin työssäolevia, ammattinsa kehittämisestä kiinnostuneita aikuisia! Meidän tulkintamme on, että neuvottelukunta tähtää täystyöllisyyteen, toteutuu se sitten rakennemuutoksen myötä tai aikuiskoulutusta lisäämällä. 
Yksi tekijä, mihin koulutuksella voidaan varmasti vaikuttaa, oli ylijäämäväen varastointi, mikä onkin ollut koulutuksen keskeinen funktio jo pitkään (vrt. Ahola 1988; Kivinen \& Rinne 1988; Jolkkonen 1987).

Työelämän ja koulutuksen välisten suhteiden osalta rakennemuutoksen hallintaan pyritään nimenomaan koulutusjärjestelmän uudistamisen kautta. Eri intressitahojen lausumista voidaan jäljittää "rakennemuutosmalli", mihin myös Väestön koulutus 2000 -mietintö liittyy. Siinä ennustetaan teknologisesta kehityksestä seuraavan suuria muutoksia työelämässä. Työvoiman perinteisten kvalifikaatioiden ei enää sisällöllisesti katsota vastaavan muuttuvien tehtävien edellyttämiä valmiuksia, mikä puolestaan nähdään uhkana tuotannon tehokkuusvaatimuksille. (Silvennoinen, Kivinen \& Rinne 1988.)

"Koulutuksen kautta tapahtuvalla työvoiman asianmukaisella kvalifioinnilla voidaan mallin mukaan muuttuvissakin olosuhteissa taata työn mahdollisimman korkea tuloksellisuus" (mt. 9).

Kansliapäällikkö Jaakko Numminen on puolestaan nähnyt oman ministeriönsä osuuden rakennemuutoksen hallinnassa perin vastaanpanemattomasti: "Tulipa nyt vapautuva työvoima siirtymään uusiin tehtäviin tai tulipa se jäämään työttömäksi, lähes kaikissa tapauksissa huolenpito siitä jää opetustoimen vastuulle" (Numminen 1988).

Koulutussuunnittelun rakentaminen pelkästään työvoimamenetelmän varaan ansaitsee kaksi keskeistä vasta-argumenttia. Toista on jo edellä käsitelty: koulutuspaikkoja on mieletöntä perustaa aloille, mihin kukaan ei halua koulutusta. Erittäin tärkeää on myös tajuta perinteisen koulujärjestelmän puutteet työvoiman tuottajana. Kun peruskoulutuskin tänään kestää vähintään 9 vuotta ja esimerkiksi opiskeluajat korkeakouluissa kaiken aikaa pitenevät, ei koulutuksella voida vastata nopeasti työelämän akuutteihin tarpeisiin.

Koulutusjärjestelmän luontainen hitaus yhteiskunnallisissa muutoksissa asettaa myös muita kitkatekijöitä. Väestön koulutuspreferenssejä ei voida äkkiä mielivaltaisesti manipuloida. Koulutuksen yhteiskunnallisista yhteyksistä juontuva välttämättömyys valikoida ihmisiä työnjaon hierarkian eri tasoille kytkee koulutusjärjestelmän työmarkkinoiden ja yhteiskunnan rakenteen omalakisiin erityispiirteisiin. Myös koulutusjärjestelmän historiallisuus kertautuu ja vaikuttaa vielä nykypäivässäkin. Samoin opettajakunnan historiallisesti ja kulttuurisesti vahva omaleimaisuus ja työmarkkinapoliittinen asema ovat tärkeitä tekijöitä pyrittäessä muuttamaan koulutusjärjestelmää vaikkapa rakennemuutosmallin mukaisesti. (Vrt. Kivinen 1988.)

\section{Lopuksi: koulutussuunnittelun vaihtoehdot}

Esityksemme ei ole käsitellyt määrällisen koulutussuunnittelun vaihtoehtoja, mutta on kuitenkin tavoitellut koulutuksen kysyntämenetelmän mahdollisuuksia ja rajoja ja vaatinut tulevaisuuden kehityksen entistä monipuolisempaa pohdintaa. Koulutussuunnittelun neuvottelukunnan ilmeinen ajatus on, että ennuste on ennuste ja sellaisena yhtä hyvă tai huono kuin mikä tahansa muu.

Joka tapauksessa kokonaisuudessaan ennusteet vakuuttavat optimistisen kehityksen jatkuvuutta, vaikka kansantalouden nopea kasvu ei kansainvälisesti ole mikään itsestäänselvyys. Esim. TASKU kutsuu bruttokansantuotteen 1.3 ja työn tuottavuuden 2.1 prosenttista kasvua kansantalouden häiriövaihtoehdoksi. Muistetaan nyt kuitenkin, että esimerkiksi Antikaisen $(1986,47)$ esitykseen on kirjattu myös sellaiset tulevaisuuden "häiriövaihtoehdot" kuin lama ja elintason lasku tai jopa "holocaust".

Miten sitten koulutussuunnittelussa voidaan ottaa huomioon erilaiset työvoimatarpeen kehitysvaihtoehdot? Keskustelu on tähän mennessä puuttunut toisaalta jouston lisäämiseen koulujärjestelmän rajakohdissa ja toisaalta koulutuksen painopisteen siirtämiseen lyhytkestoiseen, nopeasti järjestettävään koulutukseen. Pitkälti jälkimmäiseen periaatteeseen nojaa nyt kaavailtu aikuiskoulutuksen ekspansio. Koulutusalojen koulutussisältöjen vaihdettavuuteen liittyvät kokeilut ovat puolestaan esimerkkejä edellisestä.

Kolmannen vuosituhannen ongelmien pohtiminen tuntuu kirjaimellisestikin toisaikaiselta niin kauan kuin tämän päivän perusongelmat ovat ratkaisematta. Lopuksi tarkastelemmekin yhtenä ajankohtaisena ongelmana ylioppilassuman kohtaloa neuvottelukunnan esittämien tavoitteiden pohjalta.

Neuvottelukunnan mukaan työvoiman kysyntäkehitys ei edellytä korkeakoulujen sisäänoton kasvattamista vuoteen 2000 mennessä. Mietinnön mukaan nuoruusiän koulutuksen aloituspaikkatavoite on suurin piirtein sama kuin vuonna 1987 aloittaneiden määrä (15 000). Aikuiskoulutus lisääntyy vuoden 1987 noin 1900 aloittaneesta 2 590:een vuonna 2000. Koulutuksen kysyntämenetelmän so- 
veltaminen puolestaan edellyttäisi vähintäin 10000 uutta aloituspaikkaa. Jää siis nähtäväksi murtaako kuohuva elämä suunnittelijoiden padot jälleen kerran (vrt. Numminen 1987, 160).

Vähän on pohdittu ja vielä vähemmän tutkittu, mitä vaikutuksia koulutuksen kysyntää vastaavalla tarjonnalla olisi esim. työmarkkinoilla. Ehkä ne eivät olekaan suuria; koulutetut ovat tähänkin asti voineet sijoittua laaja-alaisesti, varsinkin niillä aloilla, missä varsinainen ammattitaito opitaan pääasiassa työssä. Sijoittumista voitaisiin edelleen helpottaa muuttamalla koulutuksen sisältöjä yleisten perusvalmiuksien suuntaan ja soveltamalla esim. neuvottelukunnan ideaa ammattiperheistä. Tällöin koulutuksen tulisi tarjota yksittäisen ammatin sijasta valmiudet koko ammattiperheen tehtäviin. Näin voitaisiin vastata ammattirakenteen kehitykseen vaativampien tehtäväkokonaisuuksien suunnassa. Myös automatisoituminen, elektroniikan ja tietotekniikan käyttöönotto lähentää - ainakin tekniikan - aloja toisiinsa. Samoin esimerkiksi terveydenhuollon alalla ammattiperhekoulutus avaa lupaavat näköalat.

Koulutuksen kysynnässä on toinen aspekti, joka on nähtävissä kautta peruskoulutuksen historian. Kun koulutukseen sisältyvät lupaukset sosiaalisesta noususta ja hyvästä ammatillisesta sijoittumisesta on tuotu yhä useampien ulottuville, on jouduttu tilanteeseen, jossa "liian moni" tavoittelee korkeaa koulutustasoa ja yhteiskunnallista asemaa (ks. Ahola 1988). Koulutuksen määrällisellä suunnittelulla vaikutetaan myös koulutukselliseen valikointiin (ks. Kivinen 1988). Rakennemuutoksen paljon lupauksia sisältävään terminologiaan puettuna sama tavoite on kirjattu neuvottelukunnassa näin: "Lukion tulisi ohjata nykyistä paremmin oppilaitaan myös ammatilliseen koulutukseen ja antaa tietoja työelämästä ja yleensä sellaista arkielämäntietoutta, joka lisää koulutuksen saaneiden valmiuksia elää tämän päivän ja tulevaisuuden yhteiskunnassa" (s. 28).

Osastopäällikkö Aulis Lintusen mietintöön liittämän eriävän mielipiteen mukaan asioiden käsittely neuvottelukunnassa muodostui "työmarkkinaosapuolten yksittäisiksi kannanotoiksi yksittäisiin kysymyksiin". Kukin edustettuna oleva intressitaho pyrki "saamaan varatuksi itselleen mahdollisimman suuren osan koulutettavien nuorten ryhmästä. Ne työelämän alat, jotka eivät ole neuvottelukunnassa edustettuina, ovat luonnollisesti jääneet vaille riittävää huomiota." Lintusen mukaan "mietinnön lopputulokseksi onkin muodostunut työmarkkinaneuvottelun kaltainen tulos" (s. 286).

Neuvottelukunnan ulkopuolisina emme tietenkään voi kiistää tätä. Sen sijaan voimme ounastella, että kaikkein kiivaimmilta yhteeno- toilta on voitu jopa välttyä. Lupaahan suunnitelma aikuiskoulutuksen laajentamista, ja kasvavaa kakkua on melko helppo jakaa. Kenenkään osuutta ei tarvitse pienentää siten, että saavutetut edut vaarantuisivat.

Eriävän mielipiteen viesti on kuitenkin selvä. Koulutuksen suuntaamisen tulee perustua intressinäkökohtien sijasta objektiivisesti tutkittuihin eri tahojen todellisiin tarpeisiin. Jäämmekin ihmettelemään yhteiskuntatieteellisen tutkimuksen vähäistä panosta kaavailtaessa väestön koulutusta vuonna 2000.

\section{Lähteet}

Ahola, Sakari 1988. Koulutusvirtojen kasaantuminen. Peruskoulutusjärjestelmän laajenemisesta lähtevä tarkastelu koulujärjestelmän nykytilaan ja vähän kehittämiseenkin. Suomen kasvatustieteellinen aikakauskirja Kasvatus 9, 6.

Antikainen, Ari 1986. Koulutuksen tulevaisuus ja koulutuspolitiikka. Jyväskylä.

Haavio, Matti 1988. Aikuisväestön koulutus 2000. Aikuiskasvatus 8, 3, 27-31.

Jolkkonen, Ari 1987. Koulutuksen varastointihypoteesi. Joensuun yliopisto, Kasvatustieteiden tiedekunnan selosteita 17. Joensuu.

Kivinen, Osmo 1988. Koulutuksen järjestelmäkehitys. Peruskoulutus ja valtiollinen kouludoktriini Suomessa 1800- ja 1900-luvuilla. Turun yliopiston julkaisusarja C 67 . Turku.

Kivinen, Osmo \& Rinne, Risto 1988. Valikointi, koulutus ja työ. Suomen kasvatustieteellinen aikakauskirja Kasvatus 9, 6.

Numminen, Jaakko 1988. Yliopistokysymys. Keuruu. saus. Kansalaiskasvatuksen keskus ry., julkaisuja 75. Helsinki.

Numminen, Jaakko 1987. Yliopistokysymys. Keuruu

Silvennoinen, Heikki, Kivinen, Osmo \& Rinne, Risto 1988. Rakennemuutoksen koulutusstrategiat. Lähtökohtia "uuden" aikuiskoulutuksen tutkimukseen ja arviointiin. Turun yliopisto, sosiologisia tutkimuksia 120. Turku.

Suomen kansantalouden kasvumahdollisuudet 1985-2000. Taloudellinen suunnittelukeskus. Helsinki 1985.

Tilastotiedotus KO 1987:20. Ammatilliset oppilaitokset 1986. Tilastokeskus, Helsinki 1987.

Tilastotiedotus KO 1988:4. Ammatillisten oppilaitosten oppilaaksi otetut ja oppilaat 1987. Tilastokeskus, Helsinki 1988.

Tiuri, Marti 1986. Suomi matkalla tulevaisuuteen. Keuruu.

Työmarkkinoiden tulevaisuus. Työvoiman kysyntä vuoteen 1995 ja tarjonta vuoteen 2000. Työvoimaministeriö, Suunnitteluosasto, Työvoimapoliittisia tutkimuksia nro 73, Helsinki 1988.

Väestön koulutus 2000. Komiteanmietintö 1988:28. Helsinki. 


\section{AIKUISKASVATUS \\ The Finnish Journal of Adult Education \\ Vol. 8,4/88 \\ ISSN 0358-6197 \\ Summary}

Kivinen Osmo, Rinne Risto, Ahola Sakari \& Kankaanpää Arto. 1988. Toward the readvent of adult education through the traditional methods of educational planning.

- The article deals with the quantitative forecasting methods and goal setting in educational planning used by the Education of the Population 2000 Report. Particular attention is directed at the use of alternative methods in manpower forecasting and the possibilities of the demand approach to education, at the importance of the population's training preferences, at the problems of the expansion of adult education, and at the contribution of training to the possible control of the on-going structural change in economy. 